\title{
Quantification and classification of the main environmental impacts on a Halodule wrightii seagrass meadow on a tropical island in northeastern Brazil
}

\author{
MARIA ELISA PITANGA ${ }^{1}$, MANUEL J.F. MONTES ${ }^{1}$, KARINE M. MAGALHÃES ${ }^{2}$ and THIAGO N.V. REIS ${ }^{1}$ \\ ${ }^{1}$ Universidade Federal de Pernambuco/ UFPE, Departamento de Oceanografia, \\ Rua da Arquitetura, s/n, Cidade Universitária, 50670-901 Recife, PE, Brasil \\ ${ }^{2}$ Universidade Federal Rural de Pernambuco/ UFRPE, Departamento de Biologia, \\ Rua Dom Manoel de Medeiros, s/n, Dois Irmãos, 52171-900 Recife, PE, Brasil
}

Manuscript received on March 29, 2010; accepted for publication on February 9, 2011

\begin{abstract}
Multiple stress mechanisms have caused a worldwide decrease in seagrasses, which are vulnerable to environmental and/or anthropogenic pressure. The loss of seagrass meadows of Halodule wrightii is reported for the littoral of Itamaracá Island (Northeastern Brazil). The present study identified the main anthropogenic factors that negatively influenced over the abundance and distribution of seagrass meadows between July and September 2007 at the Jaguaribe and Pilar Beaches, Eastern littoral of Itamaracá. Anthropogenic impact included the discharge of untreated sewage through fluvial channels, urban and commercial development along the coast, the anchoring of motorized and non-motorized boats, diverse fishing techniques and the dumping of solid waste. The data indicates that the Pilar is an environment with a higher impact index $(71.43 \%)$ when compared with the Jaguaribe $(57.14 \%)$, standing out the number of boats with a central motor, the total number of boats, the presence of shellfish gatherers and coastal urban development. The present study reinforces the need for defining management and conservation measures for this ecosystem, which has high ecological and economic value.
\end{abstract}

Key words: conservation, ecological value, habitat loss, marine habitat.

\section{INTRODUCTION}

The increase of the environmental pressure results in the degradation of estuaries and coastal areas, which causes changes in habitats and affects the distribution of species (Lotze et al. 2006). Seagrass meadows are among the most affected ecosystems, with reductions in their coverage area being reported worldwide (Ceccherelli et al. 2007, Creed and Amado

Correspondence to: Maria Elisa Pitanga

E-mail: melisapitanga@yahoo.com.br
Filho 1999, Duarte et al. 2004, Francour et al. 1999, Huang et al. 2006, Kirkman 1997, Schaffelke et al. 2005, Short et al. 2006, Short and Wyllie-Echeverria 1996, Walker et al. 1989, Walker and McComb 1992). These reductions are related to a variety of direct and indirect human activities (Baden et al. 2003, Hastings et al. 1995, Hemminga and Duarte 2000, Huang et al. 2006, Walker et al. 1989), as well as to global climate changes (Short et al. 2006).

Although natural events are responsible for acute, large-scale losses of seagrass habitats, the 
frequency with which such loss has occurred suggests that the increase of human population has become an important cause of disturbance to these habitats around the world (Short and Wyllie-Echeverria 1996, Hemminga and Duarte 2000). The rate of decline of seagrass meadows has accelerated in the past decades (Waycott et al. 2009), and these sensitive habitats can act as early indicators of degradation (Freeman et al. 2008).

The ecosystems formed by these plants are valuable in terms of ecological services provided to the environment. Seagrass meadows also represent about $11.5 \%$ of the dollar value of the total annual flow of services provided by terrestrial and aquatic ecosystems worldwide (Constanza et al. 1997). The loss of seagrass habitats decreases primary production, carbon sequestration and cycling nutrients in the coastal zone (Worm 2006). Considering the energy these plants provide to other ecosystems, such as adjacent coral reefs or distant deep-sea bottoms, the continued loss of seagrass meadows also leads to a decrease in their net secondary productivity (Heck et al. 2008).

In Brazil, information on the environmental impact on seagrass meadows is scarce (Creed and Amado Filho 1999, Magalhães and Alves 2002, Magalhães et al. 2003, Magalhães and EskinaziLeça 2000, Short et al. 2006). Field observations and reports from local fishermen (Magalhães and Alves 2002) indicate the loss of seagrass coverage on Itamaracá Island, which is considered the most important estuarine complex in the state of Pernambuco (northeastern Brazil). The seagrass meadows of Itamaracá Island are the densest of all meadows in the country and also have the greatest biomass values (K.M. Magalhães, unpublished data). Halodule wrightii is the most abundant and well-distributed seagrass on the coast of the state of Pernambuco, including Itamaracá Island. This species is found in shallow waters and sheltered locations, with soft bottoms in estuaries and lagoons formed by coral reefs (Kempf 1970).
The aim of the present study was to identify anthropogenic factors that may have a negative influence over the abundance and distribution of Halodule wrightii seagrass meadows on Itamaracá Island, and generate data for the drafting of an effective conservation program for this ecosystem.

\section{MATERIALS AND METHODS}

STUDY AREA

The Jaguaribe and Pilar sites are located in the eastern littoral zone of Itamaracá Island, Pernambuco State, northeastern Brazil ( $7^{\circ} 43^{\prime} 46.9^{\prime \prime} \mathrm{S}, 34^{\circ} 49^{\prime} 32.5^{\prime \prime} \mathrm{W}$ and $7^{\circ} 45^{\prime} 12.7^{\prime \prime} \mathrm{S}, 34^{\circ} 49^{\prime} 25.6^{\prime \prime} \mathrm{W}$, respectively) (Figure 1). The climate is defined by two distinct seasonal periods: a dry season from September to February and a rainy season from March to August. Mean precipitation and temperature for the region are $1763 \mathrm{~mm} /$ year and $26^{\circ} \mathrm{C}$, respectively (Andrade and Lins 2005). The area is characterized by quartz and bio-detritus calcareous sand sediments (Kempf 1970).

\section{IMPACT MEASURES AND FIELD SURVEY}

An interaction matrix for the field surveys (Tommasi 1994) was constructed with the anthropogenic impact variables that direct or indirectly affect seagrass coverage worldwide, as reported in the literature (scientific papers, technical documents, specialized books and field observations). With this matrix, six surveys were carried out at the Jaguaribe and Pilar sites between July and September 2007. The length traversed for each site ranged from 1 to $1.2 \mathrm{~km}$ at Jaguaribe and Pilar, respectively. Each survey was conducted in several 10-meter transects parallel to the coastline and above the high-tide mark. The different forms of impact at each site were quantified, classified and photo documented. Solid waste and containment structure were not quantified, but photographed. 


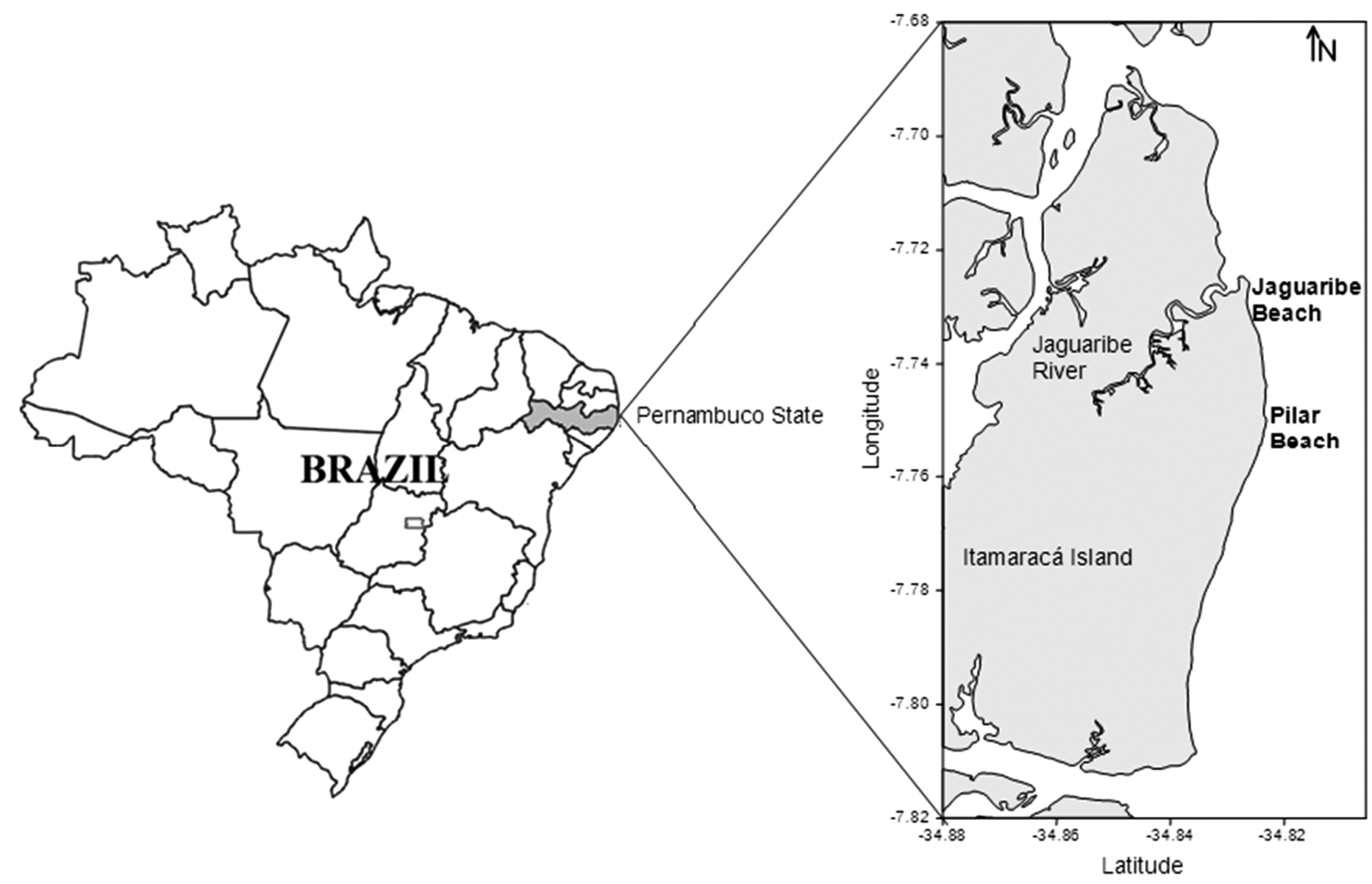

Figure 1. Study area - Jaguaribe and Pilar sites, Itamaracá Island, Pernambuco, Brazil.

\section{DATA ANALYSIS}

The importance of different forms of impact with regard to the effects on $H$. wrightii meadows was established based on the numerical scale proposed by Singer (1985). Thus, the forms of impact were assessed in four levels: no effect (0); negligible to moderate effect (1); significant effect (2) and extreme effect (3). The impact importance index at each site was determined from the sum of the numeric values attributed to each form of impact. Order and state criteria were used to describe the different forms of impact on $H$. wrightii meadows, as suggested by Feuerschutte (1993). Order was described as direct (impact resulting directly from action) or indirect (unexpected action or caused by a secondary impact). State criteria were described as temporary (effect with particular duration), permanent (effect remaining for a known period of time after the action has ceased) or cyclic (effect appearing in known periods of time). The
Statistica 8 program (StatSoft Inc.) was used to perform the analysis of variance (ANOVA). Oneway ANOVA was used to determine significant differences in impact between sites. Tukey's test was used to identify specific differences. The level of significance was set at $p=0.05$.

\section{RESULTS}

DESCRIPTION OF FORMS OF IMPACT

At both sites, different anthropogenic forms of impact involved the discharge of untreated sewage through pluvial channels, urban and commercial development along the coast, the anchoring of motorized and nonmotorized boats, fishing techniques and the dumping of solid waste. These different forms of impact are described below.

Pluvial channels and sewage outlets were recorded at both sites. Three pluvial channels were located at Jaguaribe, and one pluvial channel and a sewage outlet were recorded at Pilar. The channels 
are used to discharge untreated sewage directly onto the beach, as the area does not have a proper sewage collection and treatment system (SNIS 2010).

The sites are frequently used for recreational activities, and a total of 46 vending kiosks and 114 houses were recorded in the study area. Jaguaribe was more frequently used for tourism and had 78\% of the kiosks, but only $34 \%$ of the total number of houses. All buildings at the Jaguaribe site were located in the supralittoral zone, exceeding the mean maximal high tide level in some cases. Pilar had a greater number of houses $(66 \%)$ and $22 \%$ of the total number of kiosks. Most constructions at the Pilar site were built on the shoreline at the high tide limit, causing erosion and resulting in the need for containment structures made of brick. At the Jaguaribe site, these structures were generally built with coconut palm stems.

The total number of boats ranged from 52 to 123 at the Jaguaribe site, and 37 to 60 at the Pilar site. There was a significantly greater number of boats at Jaguaribe $(\mathrm{F}=14.44 ; \mathrm{p}=0.003)$. The number of anchored boats ranged from 16 to 43 at Jaguaribe, and 12 to 23 at Pilar, with no significant difference between sites $(F=3.56 ; p=0.088)$. The number of boats with a central motor was significantly different between sites $(F=96.29 ; p<0.001)$ (Figure 2). The impact of boat maintenance was also observed at both sites. Local fishermen use seagrass meadows for cleaning and waterproofing hulls. Both processes involve the use of brush, sea water, pitch (melted and/or dissolved in solvent), gas burners or lime and castor bean oil. In both techniques, the residue is discarded at the site.

As the population of Itamaracá Island depends heavily on a variety of aquatic organisms in the coastal ecosystem, different fishing techniques are practiced. Most techniques are handmade, consisting of crab, lobster and fish traps, trawl and casting nets, fishing sticks, harpoons and manual shellfish gathering. The use of trawl-net fishing predominated significantly (58\%) over other techniques $(42 \%)$ at the Jaguaribe site $(\mathrm{F}=11.90 ; \mathrm{p}=0.006)$. At Pilar, shellfish gathering demonstrated an important direct impact on the seagrass meadows, accounting for $94 \%$ of all fishing techniques ( $F=15.15 ; \mathrm{p}=0.003$ ). Gatherers may spend over four hours per day collecting shellfish and causing significant damage to the seagrass meadows.

Solid waste was observed at the shoreline and in the channels, consisting of plastic packaging, pieces of fishing nets, rope, nylon fishing line, steel and aluminum cans, paper, polystyrene and pieces of wood.

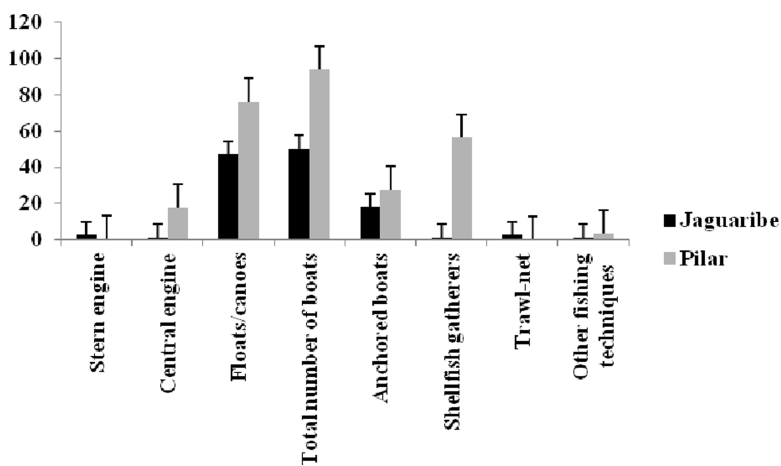

Figure 2. Main forms of anthropogenic impact recorded at the Jaguaribe and Pilar sites (Itamaracá, Brazil) between July and September 2007 using mean data.

INTERPRETATION OF IMPACT

The total impact score from the checklist applied to the Jaguaribe and Pilar sites was 23 and 25 points, respectively (Table I). The degree of importance of specific forms of impact differed between sites. For example, the number of boats with a stern motor and trawl-net activities were determined to be significant at Jaguaribe, whereas at Pilar the effect of boats with a stern motor was determined to be negligible to moderate and trawl-net activities to have not affected the ecosystem (no effect). There was a greater proportion of forms of impact classified as significant at Pilar $(71.43 \%)$ regarding the $57.14 \%$ determined for Jaguaribe (Table I). The significant forms of impact were the number of boats with a central motor, the total number of boats and the presence of shellfish 
Table I. Importance and qualification of impact on H. wrightii meadows at the Jaguaribe (J) and Pilar (P) sites from July to September 2007; Itamaracá Island, Pernambuco State, Brazil.

\begin{tabular}{l|cccccc}
\hline & \multicolumn{2}{|c}{ IMPORTANCE $^{\mathbf{a}}$} & \multicolumn{2}{c}{ ORDER $^{\mathbf{b}}$} & \multicolumn{2}{c}{ DURATION $^{\mathbf{b}}$} \\
\cline { 2 - 7 } IMPACTS & $\mathbf{J}$ & $\mathbf{P}$ & $\mathbf{J}$ & $\mathbf{P}$ & $\mathbf{J}$ & $\mathbf{P}$ \\
\hline Presence of houses on shoreline & 2 & 2 & $\mathrm{Idr}$ & $\mathrm{Idr}$ & $\mathrm{Pm}$ & $\mathrm{Pm}$ \\
Presence of bars on shoreline & 2 & 2 & $\mathrm{Idr}$ & $\mathrm{Idr}$ & $\mathrm{Pm}$ & $\mathrm{Pm}$ \\
Sewage spill/Pluvial channel & 2 & 2 & $\mathrm{Idr}$ & $\mathrm{Idr}$ & $\mathrm{Pm}$ & $\mathrm{Pm}$ \\
Tourism & 2 & 2 & $\mathrm{Idr}$ & $\mathrm{Idr}$ & $\mathrm{Tp}$ & $\mathrm{Tp}$ \\
Boat circulation (stern engine) & 2 & 1 & $\mathrm{Dr}$ & $\mathrm{Dr}$ & $\mathrm{Pm}$ & $\mathrm{Pm}$ \\
Boat circulation (central engine) & 1 & 2 & $\mathrm{Dr}$ & $\mathrm{Dr}$ & $\mathrm{Pm}$ & $\mathrm{Pm}$ \\
Boat circulation (floats/canoes) & 2 & 2 & $\mathrm{Dr}$ & $\mathrm{Dr}$ & $\mathrm{Pm}$ & $\mathrm{Pm}$ \\
Total number of boats & 1 & 2 & $\mathrm{Dr}$ & $\mathrm{Dr}$ & $\mathrm{Pm}$ & $\mathrm{Pm}$ \\
Anchoring & 2 & 2 & $\mathrm{Dr}$ & $\mathrm{Dr}$ & $\mathrm{Pm}$ & $\mathrm{Pm}$ \\
Shellfish gatherers & 0 & 2 & $\mathrm{Idr}$ & $\mathrm{Dr}$ & $\mathrm{Tp}$ & $\mathrm{Pm}$ \\
Trawl net & 2 & 0 & $\mathrm{Idr}$. & $\mathrm{ND}$ & $\mathrm{Pm}$ & $\mathrm{ND}$ \\
Other fishing techniques & 1 & 1 & $\mathrm{Idr}$ & $\mathrm{Idr}$ & $\mathrm{ND}$ & $\mathrm{ND}$ \\
Containment structure & 1 & 2 & $\mathrm{Idr}$ & $\mathrm{Idr}$ & $\mathrm{Pm}$ & $\mathrm{Pm}$ \\
\hline Total & 23 & 25 & $* * *$ & $* * *$ & $* * *$ & $* * *$ \\
\hline
\end{tabular}

ND - No data;

0 - no effect;

1 - negligible to moderate;

2 - significant;

3 - extreme;

Dr - Direct;

Idr - Indirect;

Tp - Temporary;

Pm - Permanent;

Cc-Cyclic.

Font: ${ }^{a}$ Modified from Singer (1985); ${ }^{\mathrm{b}}$ Adapted from Feuerschutte (1993).

gatherers and containment structures. No significant differences between sites were detected with regard to the qualification of the different forms of impact based on order and duration.

\section{DISCUSSION}

Global, regional and local stressors may independently result in large-scale habitat loss of seagrass meadows. This decline in the seagrass coverage worldwide can be explained by natural causes, such as extreme weather events or disease (Hemminga and Duarte 2000, Nyqvist et al. 2009). However, the effects of human impact, such as eutrophication (Burkholder et al. 2007, Lee et al. 2004) and sedimentation (Erftemeijer and Lewis 2006), are more often the main causes of loss of seagrass. The present data demonstrate that Itamaracá Island has been experiencing many of the problems described in the literature, such as the effects of tourism, the circulation of motorized boats, anchoring, disruptive fishing techniques and the discharge of untreated sewage.

The direct effect of the discharge of untreated sewage on seagrass coverage was observed at both study sites. Information from the local government confirms the lack of a sewage collection and treatment system in the area. Island residents are responsible for sewage disposal and are instructed to build septic pits, but there is no supervision to enforce the building of such pits or monitor the final destination of the waste. The coastal environment is exposed to a large number of nutrients from human activities. These nutrients have harmful effects on the structure and function of the seagrass ecosystem (Lee and Dunton 2000). The input of organic matter causes an increase in the biomass of phytoplankton (Walker and McComb 1992, McMahon et al. 1997) and epiphytic algae, which reduces both light penetration and the concentration of dissolved oxygen (Huang et 
al. 2006). Increased nutrient loads are considered the major cause of decline or lack of recovery of seagrass meadows (Hemminga and Duarte 2000). According to Giesen et al. (1990), an increasing degree of eutrophication is related to an increase in turbidity. The Brazilian Institute of Geography and Statistics (IBGE 2008) reports that Itamaracá has a population of 18,412 inhabitants. Based on the calculation used by Jürgensen (1995) to estimate the level of nutrients entering an environment, Itamaracá Island receives an input of $220.944 \mathrm{~g} / \mathrm{N}_{\mathrm{T}} /$ day/inhabitant and $883,776 \mathrm{~g} / \mathrm{P}_{\mathrm{T}} /$ day/inhabitant.

Construction in the supralittoral zone, as observed at the study sites, diminishes the supply and/or interrupts the transport of sediments, resulting in erosion and sedimentation in seagrass meadows (Short and Wyllie-Echeverria 1996). These processes have an indirect impact on the meadows, such as light attenuation and the covering of leaves, with a consequent reduction in the photosynthetic activity. Such effects, together with eutrophication, are reported to be the major causes of the decline in seagrass coverage worldwide (Kirkman 1997).

During the monitoring at Pilar beach in 2002, a sediment wave was recorded crossing a seagrass meadow, which caused the total disappearance of the meadow and the subsequent appearance of meadow fragments (K.M. Magalhães, unpublished data). Containment structures on the shoreline may cause sediment imbalances in seagrass meadows by changing the wave energy pattern, which can increase sedimentation and/or erosion and, thus, lead to the fragmentation of seagrass meadows (Walker and McComb 1992).

The intensive circulation and anchoring of motorized and non-motorized boats, as seen at both sites, have been characterized as a serious threat to the conservation of seagrass meadows worldwide (Walker et al. 1989, Kirkman 1997, Creed and Amado Filho 1999). According to Ceccherelli et al. (2007), the impact of anchoring activities, regardless of boat size, causes the small- scale degradation of these ecosystems. The impact of these activities depends on the stage of the anchoring cycle and the kind of anchor employed (Ceccherelli et al. 2007, Creed and Amado Filho 1999, Francour et al. 1999, Milazzo et al. 2004). At Itamaracá, both sites have been used as boat ports for many decades, and Pilar is also a fishing center for the Island. Boat anchoring may also cause a short-term reduction in $H$. wrightii meadow density in tropical regions (Creed and Amado Filho 1999). According to Walker et al. (1989), the scars created by moorings in the seagrass canopy affect the physical integrity of the meadow. In addition to the impact of the presence of boats, oil leakage from boat motors is an additional local stressor that affects seagrass meadows (Baden et al. 2003).

Diverse fishing techniques were observed in the study area, but two of these fishing modalities out-ranked the others in terms of the disturbance of seagrass meadows: trawl-net fishing at Jaguaribe and manual shellfish gathering at Pilar. The lack of trawling at Pilar may be related to the difference in the number of boats between the two sites as Pilar has a greater number of boats, which could make trawling difficult. According to Huang et al. (2006), trawling pulls out seagrass by the roots, thereby destroying the meadows. Some fishing techniques may disturb the sediment dynamics, which can result in a severe reduction in meadows (Hemminga and Duarte 2000, Short and WyllieEcheverria 1996) as observed at Itamaracá Island.

The low number of reports on shellfish gatherers at Jaguaribe may be related to the lower abundance and distribution of Halodule in this area in comparison to Pilar (field observation). The number of shellfish gatherers increases considerably at the Pilar site at low tide. A large number of individuals, including children, gather shellfish on the island, and this activity is a source of income for locals. The act of digging up shellfish causes seagrass to be pulled out by the roots, thereby destroying the meadows. This activity also 
covers the meadows with sediment, which affects seagrass growth (Huang et al. 2006).

Solid waste on beaches and in coastal ecosystems is regularly observed (Araújo and Costa 2004). Despite the presence of solid waste in the meadows of Itamaracá, the effects on seagrass have not yet been reported. However, there are reports on the consumption of this waste by animals that depend on the meadows, which results in drowning, deformation and death (Beck and Barros 1991, Bjorndal et al. 1994, Bugoni et al. 2001).

Based on the results of the present study, the authors suggest a permanent monitoring program for the assessment of the effects of these different forms of impact on $H$. wrightii meadows, identifying possible variations in certain seagrass parameters (meadow density and coverage, leaf growth and rhizomes per year) related to the health of the meadow (UNEP 2007). According to Nyqvist et al. (2009), monitoring and management must consider meadows an important ecosystem and establish measures for the preservation of both the seagrass and its habitat, thereby protecting other organisms associated to these meadows. The management of seagrass meadows requires an integrated approach (Borum et al. 2004), including efforts toward assessing water quality, the diversity and biomass of epiphytes, sedimentation rate and the intensity of different forms of impact.

\section{RESUMO}

Múltiplos mecanismos estressores têm causado em todo mundo declínio das angiospermas marinhas, que são vulneráveis a pressões ambientais e/ou antrópicas. A perda de prados de Halodule wrightii tem sido relatada para o litoral da Ilha de Itamaracá (Nordeste do Brasil). O presente estudo identificou os principais fatores antrópicos que influenciaram negativamente na abundância e distribuição desses prados entre Julho e Setembro de 2007 nas praias de Jaguaribe e do Pilar, litoral leste de Itamaracá. O impacto antropogênico incluiu despejo de efluentes in natura nos canais fluviais, desenvolvimento urbano e comercial na linha de costa, ancoragem de embarcações motorizadas e não- motorizadas, técnicas diversas de pesca e disposição de resíduos sólidos. Os dados obtidos indicam que Pilar é um ambiente com maior índice de impacto $(71,43 \%)$ quando comparada à Jaguaribe $(57,14 \%)$, destacandose número de embarcações com motor de centro, número total de embarcações, presença de grupos de marisqueiros e desenvolvimento urbano costeiro. $\mathrm{O}$ presente estudo reforça a necessidade de se definir políticas de manejo e conservação deste ecossistema, que possui elevado valor ecológico e econômico.

Palavras-chave: conservação, valor ecológico, perda de habitat, habitat marinho.

\section{REFERENCES}

ANDRADE GO AND LINS RC. 2005. Os climas do Nordeste. In: Vasconcelos Sobrinho J, As regiões naturais do Nordeste, o meio e a civilização, Recife: CONDEPE, p. 95-18.

ARAúJO MCB AND COSTA M. 2004. Quali-quantitative analysis of the solid wastes at Tamandaré Bay, Pernambuco-Brasil. Trop Ocean 32(2): 159-170.

BAden S, GullströM M, LundéN B, PIHL L AND Rosenberg R. 2003. Vanishing Seagrass (Zostera marina, L.) in Swedish Coastal Waters. J Hum Environ 32(5): 374-377.

BeCK CA AND BARros NB. 1991. The impact of debris on the Florida manatee. Mar Pollut Bull 22(10): 508-510.

BJoRndal KA, Bolten AB AND LAUgueux CJ. 1994. Ingestion of marine debris by juvenile sea turtles in coastal Florida habitats. Mar Pollut Bull 28(3): 154-158.

Borum J, Duarte CM, Krause-Jensen D and Greve TM. 2004. What can be done to prevent seagrass loss? In: Borum $\mathrm{J}$ et al. (Eds), European seagrasses: an introduction to monitoring and management, Ed. The M\&MS project, p. 67-71.

Bugoni L, Krause L And Petry MV. 2001. Marine debris and human impacts on sea turtles in Southern Brazil. Mar Pollut Bull 42(12): 1330-1334.

BurkHOLDER JM, TOMASKo DA AND TOUCHETTE BW. 2007. Seagrasses and eutrophication. J Exp Mar Biol Ecol 350: 46-72.

Ceccherelli G, CAmpo D and Milazzo M. 2007. Short-term response of the slow growing seagrass Posidonia oceanica to simulated anchor impact. Mar Environ Res 63: 341-349.

Costanza R ET AL. 1997. The value of the world's ecosystem services and natural capital. Nature 387: 253-260.

Creed JC AND Amado FILHO GM. 1999. Disturbance and of the macroflora of a seagrass (Halodule wrightii Ascherson) meadow in the Abrolhos Marine National Park, Brazil: an experimental evaluation of anchor damage. J Exp Mar Biol Ecol 235: 285-306.

DUARTE CM, MARBÁ N AND SANTOS R. 2004. What may cause loss seagrasses? In: Borum J et al. (Eds), European seagrasses: an introduction to monitoring and management, Ed. The M\&MS project, p. 24-32. 
ERFTEMEIJER PLA AND LEWIS RRR. 2006. Environmental of dredging on seagrasses: A review. Mar Pollut Bull 52: $1553-1572$.

FEUERSChUTTE RC. 1993. Política e legislação de proteção ambiental no Brasil. In: Avaliação de impactos ambientais, MAIA, $2^{\text {a }}$ ed., Curitiba, PR:IAP/GTZ.

Francour P, Ganteaume A AND Poulain M. 1999. Effects of boat anchoring in Posidonia oceanica seagrass beds in the Port-Cros National Park (north-western Mediterranean Sea). Aquatic Conserv 9: 391-400.

FREEMAN AS, SHORT FT, ISNAIN I, RAZAK FA AND COLES RG. 2008. Seagrass on the edge: Land-use practices threaten coastal seagrass communities in Sabah, Malaysia. Biol Cons 141: 2993-3005.

Giesen WBJT, VAn KatwiJK MM ANd Den Hartog C. 1990 Eelgrass condition and turbidity in the Dutch Wadden Sea. Aquatic Bot 37: 71-85.

HAstings K, HESP P AND KENDRICK GA. 1995. Seagrass loss associated with boat mooringas at Rottnest Island, Western Australia. Ocean Coast Manage 26(3): 225-246.

Heck KL, Carruthers TJB, Duarte CM, Hughes AR, KENDRICK G, ORTH RJ AND WILLIAMS SW. 2008. Trophic Transfers from Seagrass Meadows Subsidize Diverse Marine and Terrestrial Consumers. Ecosystems 11(7): 1198-1210.

Hemminga MA AND DuARTE CM. 2000. Seagrass Ecology, Cambridge University Press, 298 p.

Huang X, Huang L, Li Y, Xu Z, Fong CW, Huang D, HAN Q, HuANG H, TAN Y AND LiU S. 2006. Main seagrass beds and threats to their habitats in the coastal sea of South China. Chin Sci Bull 51(Supp. II): 136-142.

IBGE - INSTITUTO BRASILEIRO DE GEOGRAFIA E ESTATísTICA. 2008. http://www.ibge.gov.br/ (accessed June 27, 2008).

JÜRGENSEN C. 1995. Modelling of nutrient release from the sediment in a tidal inlet, kertingenor. Funen. Heldingor. Ophelia, Heldingor 42: 163-178.

KEMPF M. 1970. Nota preliminar sobre os fundos costeiros da região de Itamaracá (Norte do Estado de Pernambuco, Brasil). Trab Oceanog Univ Fed PE 9/11: 95-110.

KIRKMAN H. 1997. Seagrasses of Australia. Australia: State of the Environment Technical Paper Series (Estuaries and the Sea), Department of the Environment, Canberra, 36 p.

LEE KS AND DUNTON KH. 2000. Effects of nitrogen enrichment on biomass allocation, growth, and leaf morphology of the seagrass Thalassia testudinum. Mar Ecol Prog Ser 196: 39-48.

LEE KS, ShORT FT AND Burdick DM. 2004. Development of a nutrient pollution indicator using the seagrass, Zostera marina, along nutrient gradients in three New England estuaries. Aquatic Bot 78: 197-216.

Lotze HK, Lenihan HS, Bourque BJ, Bradbury RH, COOKE RG, KaY MC, KidWell SM, Kirby MX, Peterson CH AND JACKSON JBC. 2006. Depletion, degradation, and recovery potential of estuaries and coastal seas. Science 312: 1806-1809.

MAgalhÃes KM AND Alves MS. 2002. Fanerógamas marinhas do litoral do estado de Pernambuco. In: Diagnóstico da Biodiversidade de Pernambuco ed. Recife: Secretaria de Ciências, Tecnologia e Meio Ambiente, Editora Massangana 1: 173-181.
Magalhães KM, Cocentino ALM, EsKinaZI-LeÇA E, FERNANDES MLB, REIS TNV, GUIMARÃES NCL AND RodRigues HS. 2003. Seagrass meadows at the Suape Port area, Pernambuco, Brazil. In: Claudio-Sales V, Tonini IM and Dantas EWC. Anais de trabalhos completos do VI Congresso de Ecologia do Brasil, Editora da Universidade Federal do Ceará, p. 334-335.

Magalhães KM AND EsKInAZI-LEÇA E. 2000. Os prados de fanerógamas marinhas. In: Barros HM, Leça EE, Macedo SJ and Lima T (Orgs), Gerenciamento participativo de estuários e manguezais. Recife: Editora Universitária da UFPE, p. 37-49.

MCMahon K, Young E, Montgomery S, Cosgrove J, WILSHAW J AND WALKER DI. 1997. Status of a shallow seagrass system, Geographe Bay, south-western Australia. J R Soc Wes Aust 80: 255-262.

Milazzo M, Badalamenti F, Ceccherelli G AND Chemello R. 2004. Boat anchoring on Posidonia oceanica beds in a marine protected area (Italy, western Mediterranean): effect of anchor types in different anchoring stages. J Exp Mar Biol Ecol 299: 51-62.

NYQVist A, ANDRÉ C, GULLSTRÖM M, BADEN SP AND ABERG P. 2009. Dynamics of Seagrass Meadows on the Swedish Skagerrak Coast. Ambio 38(2): 85-88.

SCHAFFELKE B, Mellors J AND DuKE NC. 2005. Water quality in the Great Barrier Reef region: responses of mangrove, seagrass and macroalgal communities. Mar Pollut Bull 51: 279-296.

Short FT, Koch EW, Creed JC, Magalhaes KM, FERNANDEZ E AND GAECKLE JF. 2006. SeagrassNet monitoring across the Americas: case studies of seagrass decline. Mar Ecol 27(4): 277-289.

SHORT FT AND WyLliE-ECHEVERRIA S. 1996. Natural and human-induced disturbance of seagrasses. Environ Conserv 23: 17-27.

SINGER EM. 1985. Metodologia para avaliação dos impactos ambientais da mineração. Encontro Técnico (27/06/85) Mineração e Meio Ambiente no Estado de São Paulo, $1^{\text {a }}$ ed., São Paulo, ABGE, p. 10-20.

SNIS-SistemA NACIONAL DE INFORMAÇÕES SOBRE SANEAMENTO. 2010. http://www.snis.gov.br/ (acessed December, 2010).

TOMMASI LR. 1994. Estudo de impacto ambiental. São Paulo: Terragraph Artes e Informática, 354 p.

UNEP - United NATIONS ENVIRONMENT Programe. 2007. Guidelines for impact assessment on seagrass meadows. United Nations Environment Programe. Mediterranean Action Plan, $44 \mathrm{p}$.

WALKer DJ, LUKatelich G, BASTYAN G AND MCCOMB AJ. 1989. Effect of boat moorings on seagrass beds near Perth, Western Australia. Aquatic Bot 36: 69-77.

WALKER DJ AND MCCOMB AJ. 1992. Seagrass degradation in Australian coastal waters. Mar Pollut Bull 25: 191-195.

WAYCOTT M ET AL. 2009. Accelerating loss of seagrasses across the globe threatens coastal ecosystems. PNAS 106(30): 12377-12381.

WORM B. 2006. Impacts of biodiversity loss on ocean ecosystem services. Science 314: 787-790. 